\title{
THE MONTANA GROUP OF NORTHWESTERN MONTANA.
}

\author{
By Eugene Stebinger.
}

\section{INTRODUCTION.}

Recent field work has shown that the formations of the Montana group in and near the Blackfeet Indian Reservation of northwestern Montana are very different from those of the type area of the Judith River and associated formations on Missouri and Musselshell rivers, in the central part of the State, but similar to the formations in southern Alberta as described by Dawson. They seem to deserve special description not only because they present new evidence regarding the relations of the Belly River formation of Canada to the Judith River formation, but also because they indicate the varying geographic conditions that prevailed during Cretaceous time in this region. Furthermore, the stratigraphy as interpreted affords an excellent example of variation in sedimentation from the seaward to the landward side of a zone of deposition.

The Montana group, as here described, was first studied by the writer in the summer of 1911, along Cut Bank Creek and Two Medicine River on the Blackfeet Indian Reservation, in company with Mr. T. W. Stanton, who has already briefly described some of the features of this region ${ }^{1}$ and to whom the writer is much indebted for paleontologic determinations which, especially those for the marine formations encountered, were of great assistance in interpreting the stratigraphy. During the next two seasons these formations were traced northward into the type area of the Belly River beds, described by G. M. Dawson ${ }^{2}$ in 1885 , and eastward into an area of the Judith River formation, as definitely determined by Stanton and Hatcher ${ }^{3}$ in 1903. The interpretation of the field relations presented is therefore based primarily on the areal tracing of the formations, although every conclusion was substantiated by paleontologic evidence.

\section{FORMATIONS CONSTITUTING THE MONTANA GROUP.}

\section{SECTION ON TWO MEDICINE RIVER.}

A section showing the complete sequence of the formations of the Montana group in northwestern Montana is exposed along the valley of Two Medicine River in the southern part of the Blackfeet Indian Reservation, and because of its completeness and of the excellence of the exposures is offered as a standard for the region. The section extends westward upstream from the mouth of the river, in T. 31 N., R. 5 W., to a point about 3 miles above the Holy Family Mission (Family post office), in T. 31 N., R. 9 W. Throughout this distance, about 35 miles, the formations either lie nearly flat or dip slightly westward at an angle rarely exceeding $3^{\circ}$. As the river runs nearly at a right angle to the strike, it crosses the formations in succession from younger to older. On the whole the locality is almost ideal for a study of the formations, the structure being simple and easily determined and the rocks perfectly exposed throughout most of the distance in the minutely carved badlands along the sides of the valley.

1 Stanton, T. W., Some variations in Upper Cretaceous stratigraphy; presidential address before the Geological Society of Washington, 1912: Washington Acad. Sci. Jour., vol. 3, pp. 66-69, 1913.

2 Report on the region in the vicinity of the Bow and Belly rivers, Northwest Territory: Canada Geol. Survey Rept. Progress for 1882-1884, pp. 1-169c.

${ }^{3}$ Stanton, T. W., and Hatcher, J. B., Geology and paleontology of the Judith River beds, with a chapter on the fossil plants by F. H. Knowlton: U. S. Geol. Survey Bull. 257, pp. 51-53, 1905. 
From the top of the Colorado shale, which is readily recognized by its characteristic marine fauna and general appearance, the rocks naturally group themselves in ascending order into four lithologic units-(1) a massive gray sandstone, chiefly marine; (2) a rudely bedded mass of clay and sandstone, chiefly a fresh-water deposit; (3) a dark marine clay shale; and (4) a massive gray sandstone, brackish and marine. Nos. 1 and 3 correspond to the Virgelle sandstone, as the lower sandstone member of the Eagle sandstone has recently been designated, ${ }^{1}$ and to the Bearpaw shale of the Missouri and Musselshell river section in central Montana, whereas Nos. 2 and 4, formations hitherto not recognized, whose stratigraphic equivalents elsewhere are represented by formations having different limits and lithology, are here named the Two Medicine formation and Horsethief sandstone. The important details of the section are shown below.

Formations of the Montana group of northwest Montana exposed on Two Medicine River between its mouth and Family post office.

\begin{tabular}{|c|c|c|c|c|}
\hline Formation. & Lithology. & Fossils. & Topographic features. & $\begin{array}{l}\text { Thick- } \\
\text { ness in } \\
\text { feet. }\end{array}$ \\
\hline Horsethief sandstone. & $\begin{array}{l}\text { Gray to buff coarse-grained, much } \\
\text { cross-bedded, massive sandstone } \\
\text { in upper half. In lower half } \\
\text { slabby gray sandstone, becom- } \\
\text { ing shaly toward the base. In } \\
\text { places beds of heavy magnetite- } \\
\text { bearing sandstone. }\end{array}$ & $\begin{array}{l}\text { Mainly a brackish-water fauna } \\
\text { containing Ostrea, Corbicula, } \\
\text { Corbula,and Anomia. In places } \\
\text { a marine littoral fauna yielding } \\
\text { Tancredia americana, Cardium } \\
\text { speciosum, and Mactra. }\end{array}$ & $\begin{array}{l}\text { Where the formation lies nearly } \\
\text { horizontal it may form a bold } \\
\text { escarpment; where it is steeply } \\
\text { tilted it forms prominent hog- } \\
\text { back ridges. }\end{array}$ & 360 \\
\hline Bearpaw shale. & $\begin{array}{l}\text { Dark-gray clay shale with a few } \\
\text { limestone concretions. }\end{array}$ & $\begin{array}{l}\text { An abundant marine fauna } \\
\text { (Pierre) containing Baculites, } \\
\text { Placenticeras, Inoceramus, Avic- } \\
\text { ula, and Scaphites. }\end{array}$ & $\begin{array}{l}\text { Subdued and rounded topog- } \\
\text { raphy, gumbo soil, and few } \\
\text { exposures. }\end{array}$ & 490 \\
\hline Two Medicine formation. & $\begin{array}{l}\text { Gray to greenish-gray clay and } \\
\text { soft irregular sandstone which is } \\
\text { most abundant in the lower } 250 \\
\text { feet. In places thin beds of red } \\
\text { clay and nodular limestone. }\end{array}$ & $\begin{array}{l}\text { An abundant reptilian fauna of } \\
\text { Judith River types. At many } \\
\text { horizons a fresh-water fauna } \\
\text { containing Unio, Viviparus, and } \\
\text { Campeloma; at others brackish- } \\
\text { water forms, Ostrea, Corbula, } \\
\text { etc. One marine horizon yield- } \\
\text { ing Tancredia americana, Car- } \\
\text { dium speciosum, Mactra, land } \\
\text { plants, and much fossil wood. }\end{array}$ & $\begin{array}{l}\text { Eroded into extensive badlands } \\
\text { along principal streams; else- } \\
\text { wherea smooth rounded topog- } \\
\text { raphy. }\end{array}$ & 1,950 \\
\hline Virgelle sandstone. & $\begin{array}{l}\text { Gray to buff coarse-grained, much } \\
\text { cross-bedded, massive sandstone } \\
\text { with many ferruginous concre- } \\
\text { tions in upper half. In lower } \\
\text { half slabby gray sandstone, be- } \\
\text { coming shaly toward the base. }\end{array}$ & $\begin{array}{l}\text { Contains a poorly developed lit- } \\
\text { toral marine fauna. }\end{array}$ & $\begin{array}{l}\text { Where the formation lies nearly } \\
\text { horizontal it forms a bold es- } \\
\text { carpment in many places; } \\
\text { where it is steeply tilted it } \\
\text { forms prominent hogback } \\
\text { ridges. }\end{array}$ & 220 \\
\hline
\end{tabular}

VIRGELLE SANDSTONE AND HORSETHIEF SANDSTONE.

Both these formations are composed of massive gray to buff sandstone, and although they are 2,500 feet apart stratigraphically they are so nearly identical that they can best be described together. Each seems to be a sandy beach or near-shore deposit laid down in a retreating sea, the Virgelle representing a great recession of the Colorado sea at the close of Colorado time and the Horsethief representing an even greater recession at the close of Pierre time. The two are therefore genetically identical, each being a sandstone laid down on a marine shale in a retreating sea. Similar rocks are associated with both of these formations, each being overlain

1 Unpublished report by C. F. Bowen entitled "The stratigraphy of the Montana group" (U. S. Geol. Survey Prof. Paper 90-I), from which the following definition is quoted: "The name Eagle sandstone was given by Weed (U. S. Geol. Survey Geol. Atlas, Fort Benton folio, No. 55) to the formation overlying the Colorado shale in north-central Montana and typically exposed on Missouri River at the mouth of Eagle Creek, 40 miles below Fort Benton. In the type locality the formation as defined by Weed consists of three more or less distinct units, comprising an upper member of thin-bedded sandstone, a middle member of shale, and a lower member of massive ledge-making sandstone. This lower member is so persistent and characteristic over a large area in north-central Montana, even where the other divisions of the formation are not recognizable, that it seems desirable for purposes of description and correlation to give it a name. It is well exposed along Missouri River from the town of Virgelle, a few miles below Fort Benton, eastward, and the name Virgelle sandstone member of the Eagle sandstone has therefore been adopted by the United States Geological Survey for this division of the formation. The Virgelle sandstone member is the lower massive ledge-making sandstone of the Eagle sandstone as defined by Weed." In northwestern Montana the Virgelle sandstone is recognized as a distinct formation, and the overlying Two Medicine formation includes the equivalent of the remainder of the Eagle sandstone. 
by a thick mass of continental deposits, apparently conformable and very similar in composition and appearance.

In the section along Two Medicine River the Virgelle sandstone rises in bold cliffs above. the few feet of sandy shale that form the uppermost beds of the Colorado group exposed at the mouth of the river. From this point the sandstone, dipping very slightly westward, is continuously exposed upstream for a distance of 8 miles, forming a narrow, steep-walled canyon several hundred feet deep, which is a little-known but picturesque feature of this part of Montana. Similarly the Horsethief sandstone, where it is cut through by Two Medicine River just above Family post office, also stands out in bold cliffs over 300 feet high.

The principal fossils found in these sandstones are invertebrates, although in many places both the formations, especially the Virgelle, seem barren. The Horsethief sandstone (named for Horsethief Ridge, in the Blackfoot quadrangle) has yielded both marine and brackish water forms. The brackish water forms are mainly oysters, which are locally very abundant; the marine forms belong to the Fox Hills near-shore fauna, the dominant species being Tancredia americana and Cardium speciosum. On Two Medicine River the Virgelle sandstone is apparently unfossiliferous, but elsewhere it is known to contain a marine near-shore fauna.

\section{TWO MEDICINE FORMATION.}

The Two Medicine formation, which lies immediately above the Virgelle sandstone, is a great mass of light-colored rocks about 2,000 feet thick, consisting mainly of typical continental deposits. From the upper end of the canyon in the Virgelle sandstone, in T. 31 N., R. $5 \mathrm{~W}$., nearly all the formation is excellently exposed in badlands that extend for 20 miles upstream to the mouth of Badger Creek, in T. 31 N., R. 8 W. It is composed principally of light-gray to greenish-gray clay and clay shale, so rudely bedded that it is impossible to follow a given stratum for any great distance. In places the beds of clay are variegated, red and yellow strata appearing. Thin nodular and nompersistent limestone, apparently of freshwater origin, also occurs at irregular intervals. Probably 20 per cent of the total mass of the formation is made up of soft coarse-grained sandstone in lenticular beds which, even where 20 to 30 feet thick, can not be traced more than 1 or 2 miles. At many localities these sandstones show the very irregular cross-bedding that is characteristic of eolian deposits. The lower 200 feet of the formation is more sandy than the remainder, probably half of this part consisting of massive sandstone in irregular beds, the thickest measuring 50 feet.

A well-developed vertebrate fauna, chiefly dinosaurs of Judith River types, occurs in this formation. The abundance of fossil bones, especially in the upper 200 feet, is unusual. C. W. Gilmore, ${ }^{1}$ of the United States National Museum, who spent the season of 1913 in collecting from these beds, noted parts of 13 different individuals of dinosaurs in the course of a single day's field work. Much of the material collected by him is new and will add greatly to our knowledge of the Cretaceous reptiles. Fragments of fossil wood and many complete sections of tree trunks are also very common throughout the formation. All the plant remains collected were identified by F. H. Knowlton as "Belly River or Judith River."

The fossil shells found in the Two Medicine formation also indicate that it is essentially of continental origin, Unio, Viviparus, and other fresh-water genera being found at many horizons. In the lower, sandy part of the formation, as well as at the top, there are local thin brackishwater beds with Ostrea, Corbula, and Corbicula. A fauna indicating a temporary incursion of purely marine waters while the formation was being deposited occurs in a sandstone about 200 feet above its base and has already been characterized by Mr. Stanton ${ }^{2}$ as a Claggett-Fox Hills fauna. It is almost identical with the fauna found at the top of the Horsethief sandstone, a fact that shows that it existed in the shallow-water portions of the Pierre sea throughout nearly all Montana time.

1 Personal communication.

${ }^{2}$ Stanton, T. W., Some variations in Upper Cretaceous stratigraphy: Washington Acad. Sci. Jour., vol. 3, p. 66, 1913. 


\section{BEARPAW SHALE.}

The Bearpaw shale is a typical dark marine clay shale averaging 500 feet in thickness in this part of the State. The change in the character of the rocks from the Two Medicine formation to this one is very abrupt, there being practically no transition beds near the contact, and although shallow water must have existed for some time at this horizon while the Bearpaw sea was advancing, no trace of the marine fauna of Fox Hills facies, noted in the Two Medicine formation and above in the Horsethief sandstone, has yet been found here. Invertebrate fossils are abundant in concretions throughout the shale and are of characteristic Pierre types, allowing fairly close and certain correlation with the Bearpaw shale of central Montana.

\section{RELATIONS OF THE MONTANA GROUP TO THE BELLY RIVER AND JUDITH RIVER FORMATIONS.}

The age of the Judith River formation and its correlation with the Belly River formation of Canada have been under discussion, mainly by paleontologists, ever since the Judith River beds were first studied. Nearly every worker who during the last 40 years has been interested in the Cretaceous formations of the Rocky Mountain and Great Plains regions has taken part in this discussion, the extensive literature of which has been thoroughly reviewed by Stanton and Hatcher. ${ }^{1}$ In 1902, on the publication of Lambe and Osborn's report ${ }^{2}$ on the vertebrate fauna of the Belly. River formation, the controversy ${ }^{3}$ was revived with renewed vigor. So great a difference of opinion was developed during the following winter that Stanton and Hatcher decided on a joint field investigation, which they made in the summer of 1903 . The results of their work were published first in a preliminary note ${ }^{4}$ and later in a detail report. They determined the succession of formations in the Montana group for the central Montana region, which has since been found to extend over a large area, and proved the Cretaceous age of the Judith River formation. Then, by means of practically continuous exposures, they traced the Judith River formation into the extreme southeastern part of the large area of Belly River beds, as originally mapped by G. M. Dawson. ${ }^{5}$ This led to their second important conclusion, namely, that the Belly River formation and the Judith River formation are of identical age. Their conclusions were generally accepted as having satisfactorily answered this much-discussed question in Cretaceous stratigraphy. There was no reason to suspect that the type section of the Belly River beds as described by Dawson, occurring on Belly River, was different from that in the locality into which they had traced the Judith River formation. That these sections are different appeared only when the section here described was examined and compared both with Dawson's section and with the section of Stanton and Hatcher on Missouri River.

In a recent paper ${ }^{6} \mathrm{~A}$. C. Peale again raises the question of the age of the Judith River formation. He does not deny the existence of the formations of the Montana group in central Montana in the succession ae originally described by Stanton and Hatcher, nor that they extend over a large area in central Montana, as proved by C. F. Bowen, R. W. Stone, and other workers, but contends that beds originally called Judith River in the type area on the Missouri near the mouth of Judith River are of Lance age and are not equivalent to the formations mapped as Judith River over a large part of Montana. Peale's contention thus raises the question of the exact interpretation of the structure and stratigraphy in the small disturbed type area at the mouth of Judith River, and if his view is substantiated the name Judith River, as applied to the formation which has been so extensively mapped under that name, will be

\footnotetext{
1 Stanton, T. W., and Hatcher, J. B., Geology and paleontology of the Judith River beds: U. S. Geol. Survey Bull. 257, pp. 14-31, 1905.

2 On vertebrate of the mid-Cretaceous of the Northwest Territory: Lambe, L. M., New genera and species from the Belly River series (midCretaceous); Osborn, H. F., Distinctive characters of the mid-Cretaceous fauna: Canada Geol. Survey. Contr. Canadian Paleontology, vol. 3, pl. 2 , 1902.

3 Science, new ser., vols. $16,17,18$

4 Hatcher, J. B., and Stanton, T. W., The stratigraphic position of the Judith River beds and their correlation with the Belly River beds: Science, new ser., vol. 18, pp. 211-212, 1903.

5 Canada Geol. Survey Rept. Progress for 1882-1884, pp. 1-169c.

6 Jour. Geology, vol. 20, pp. 530-549.
} 
invalidated. Therefore, without entering into the question raised by Peale, it is important to insist that the correlations made later in this paper refer to the formation mapped as Judith River over nearly all of central Montana.

In the course of their stratigraphic study in central Montana, Stanton and Hatcher established the succession shown in the following table:

Section of Cretaceous rocks in central Moniana.

\begin{tabular}{|c|c|c|}
\hline Formation. & Character of rocks and fossils. & $\begin{array}{l}\text { Thick- } \\
\text { ness in } \\
\text { feet. }\end{array}$ \\
\hline Bearpaw shale.. & Dark clay shale with marine fauna. & $750 ?$ \\
\hline $\begin{array}{l}\text { Judith River formation. } \\
\text { Claggett formation...... }\end{array}$ & Variable shale and soft sandstone with dinosaurs and other reptiles and fresh and brackish watershells.. & 500 \\
\hline Claggett formation....... & $\begin{array}{l}\text { Dark clay shale with several beds of sandstone, especially in the upper part; marine fossils throughout, } \\
\text { those of the sandstone including many Fox Hills species. }\end{array}$ & $400 \pm$ \\
\hline Eagle sandstone. & White, gray, and yellowish massive sandstone in lower and shale, coal, and thin sandstone in upper part. & $200-300$ \\
\hline Colorado shale. & Dark marine shale........................................ & $800+$ \\
\hline
\end{tabular}

On comparing this section with that on Two Medicine River, the Colorado shale, which can be traced continuously from its outcrops on Missouri River to those at the mouth of the Two Medicine and is also easily recognized because of its characteristic marine fauna and appearance, affords a safe stratigraphic datum plane on which to base comparative sections. First of all, the identification of the sandstone lying above the Colorado shale in the Two Medicine section as the lower or Virgelle sandstone member of the Eagle is made fairly certain by both its position and the fact that it also can be traced on the outcrop over the greater part of the distance from the exposures on Two Medicine River to those on the Missouri at the type locality, though its limits may vary slightly from point to point. The outcrop of this sandstone can be traced without interruption in bold cliff exposures from the mouth of Two Medicine River to the Sweetgrass Hills. From this locality to the outcrops of the Eagle, near Virgelle, on the Missouri, the bedrock formations are completely covered with drift, but the continuity of the sandstone over all of this distance is suggested by its presence in a well boring in T. 34 N., R. 8 E. The formation recognized as Bearpaw on Two Medicine River can not be traced to Missouri River in the same manner because it has been eroded away between these localities, but fortunately a characteristic marine fauna is found in the shale, which, together with the lithologic appearance, thickness, and relative position of the formation above the Colorado shale, makes its correlation with the Bearpaw shale of the Missouri River section about as certain as a correlation of this sort can be. This leaves the Two Medicine formation occupying the entire interval between the Virgelle sandstone and the Bearpaw, and it is therefore equivalent to all the strata on Missouri River that make up the Judith River formation, the Claggett formation, and the coal-bearing shale and sandstone forming the upper member of the Eagle sandstone.

In his report on the region in the vicinity of the Bow and Belly rivers Dawson ${ }^{1}$ established the following section for the Cretaceous rocks occurring there:

Section of Cretaceous rocks near Bow and Belly rivers, Canada.

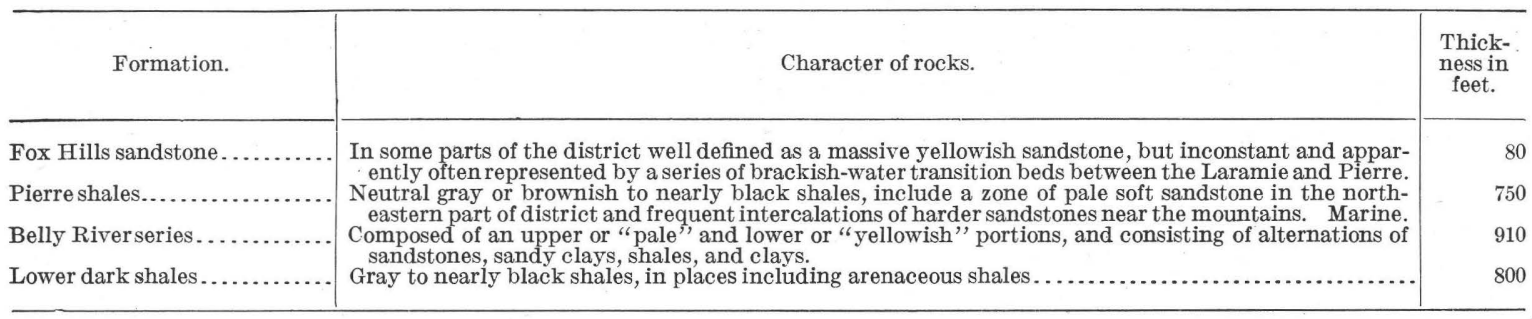

This section was compared with the section on Two Medicine River and it was fortunately found possible to trace all the members of the Two Medicine section due north to the equivalent parts of the section in Alberta without interruption in the outcrops. The Colorado shale 
exposed at the mouth of Two Medicine River can be traced directly into an area near the international boundary mapped by Dawson as Lower dark shales. The Bearpaw shale can be traced with equal facility into the shale mapped by Dawson as Pierre, and the Horsethief sandstone into Dawson's Fox Hills sandstone. The strata designated by Dawson the Belly River series comprise all the rocks between his Lower dark shales and Pierre shales, so that if his Lower dark shales are Colorado shale, and his Pierre shale is Bearpaw, it becomes evident that his Belly River series, lying between these two marine shales, is equivalent to the Virgelle sandstone and Two Medicine formation taken together, for they lie between the same two marine shales and the formations are entirely conformable; or, carrying the correlations to Stanton and Hatcher's section on Missouri River, it is apparent, from the correlation between the section on Two Medicine River and that on the Missouri, already made, that the Belly River formation of Canada is equivalent to the Eagle, Claggett, and Judith River formations combined.

The correlations made by Stanton and Hatcher in 1903, by tracing the Judith River formation up Milk River into Canada to beds mapped as Belly River by Dawson, leading them to the conclusion that the Belly River and Judith River formations were identical, are correct as far as they had gone, as can be understood by reference to the diagram (fig 9). Starting from the section in central Montana, they traveled northwestward, following the wedge of the Judith River formation to a point on Milk River near Pakowki Lake in Alberta, where the section is as at A in the accompanying diagram and there found Claggett shale beneath the Judith River formation. But Dawson had already mapped the beds found in this locality as Belly River, so that Stanton and Hatcher were justified in assuming the identity of the Belly River and Judith River formations. Dawson had also seen and described the dark marine shale of the Claggett near Pakowki Lake, but had erroneously correlated it with his Lower dark shales (Colorado shale) of the area he mapped farther west, so that the formation he had mapped as Belly River in the vicinity of Pakowki Lake included only a part of the Belly River formation as he had defined it in his type area along Belly River.

Dawson's error in correlating beds in different parts of the area originally mapped as Belly River, although suspected by Stanton and Hatcher, ${ }^{1}$ has apparently never been recognized by Canadian geologists, for since the publication of Stanton and Hatcher's report they have assumed that the section of the Montana group occurring on the Missouri in central Montana was applicable to all the area of southern Alberta up to the base of the Rockies. This seems evident from a report by D. D. Cairnes, of the Canadian Geological Survey, on the Moose Mountain district, ${ }^{2}$ a tract lying adjacent to the mountain front in the "disturbed belt" on the west edge of the large area originally mapped by Dawson. Cairnes has described Claggett shale from this district, but, reasoning from our present understanding of the relations between the Judith River and Claggett formations to the beds mapped by Dawson as Belly River, it seems highly improbable that a lithologic unit equivalent to the Claggett shale exists at any point in the western part of the area originally mapped by Dawson. Cairnes, because of the intricate structure of the foothill belt near the mountains, has probably mistaken areas of Bearpaw shale for the Claggett, to which it is very similar both lithologically and in fossil content.

\section{RELATIONS OF THE CONTINENTAL TO THE MARINE SEDIMENTS IN THE} MONTANA GROUP.

The formations at the locality on Two Medicine River described in this paper lie near the western edge of the Cretaceous interior basin. (See index map on fig. 9, showing the Cretaceous deposits of the interior basin of North America.) No areas west of this locality afford exposures of the Montana group belonging to this basin, so that by comparing sections of the Montana from the Black Hills region, the central Montana region, and the section on Two Medicine River, all of which lie approximately on a straight line, we are able to present correlations of this part of the Cretaceous from a point near the center of the Cretaceous basin to a point on the western

\footnotetext{
${ }^{1}$ Stanton, T. W., and Hatcher, J. B., Geology and paleontology of the Judith River beds: U. S. Geol. Survey Bull. 257, pp. 24-25, 1905.
}

2 Moose Mountain district of southern Alberta: Canada Geol. Survey Bull. 968, pp. 26-29, 1907. 
edge of the strata as they now remain. In other words, we can show the relations, definitely in some areas and with probability in others, of the sediments that must have been deposited near the center of this Montana sea to those along its western margin.

These relations are illustrated in the diagram forming figure 9 . The section at each of the localities given is built up on the top of the Colorado group as a datum plane, the rock units being all conformable and the thicknesses drawn to scale, so that the relative thickening or thinning of these units is properly indicated. The sediments that are mainly continental are indicated by open lining, those that are mainly marine are shown in closer lining, and the three important sandstone units of the group are shown in a stippled pattern. The general thickening of the strata on the landward side of the basin, due to the increase in the supply of material, is evident at a glance. The record from the top of the Colorado shale, a horizon that probably marks the period of maximum extent of the Upper Cretaceous sea in this region, shows a series of advances and retreats of the sea on the westward or landward side of this basin, while marine conditions to the east or seaward side remained undisturbed. These were, as indicated by arrows on the diagram, first, a marked recession of the sea during which the Virgelle sandstone was laid down, followed immediately by the piling up of continental sediments which in the section on the Two Medicine are represented by the strata at the base of the Two Medicine formation; next an advance of the sea which did not reach so far as Two Medicine River except in probably only one brief epoch, during which the wedge of the marine Claggett shale was deposited; next a second recession, during which again a shore sand-

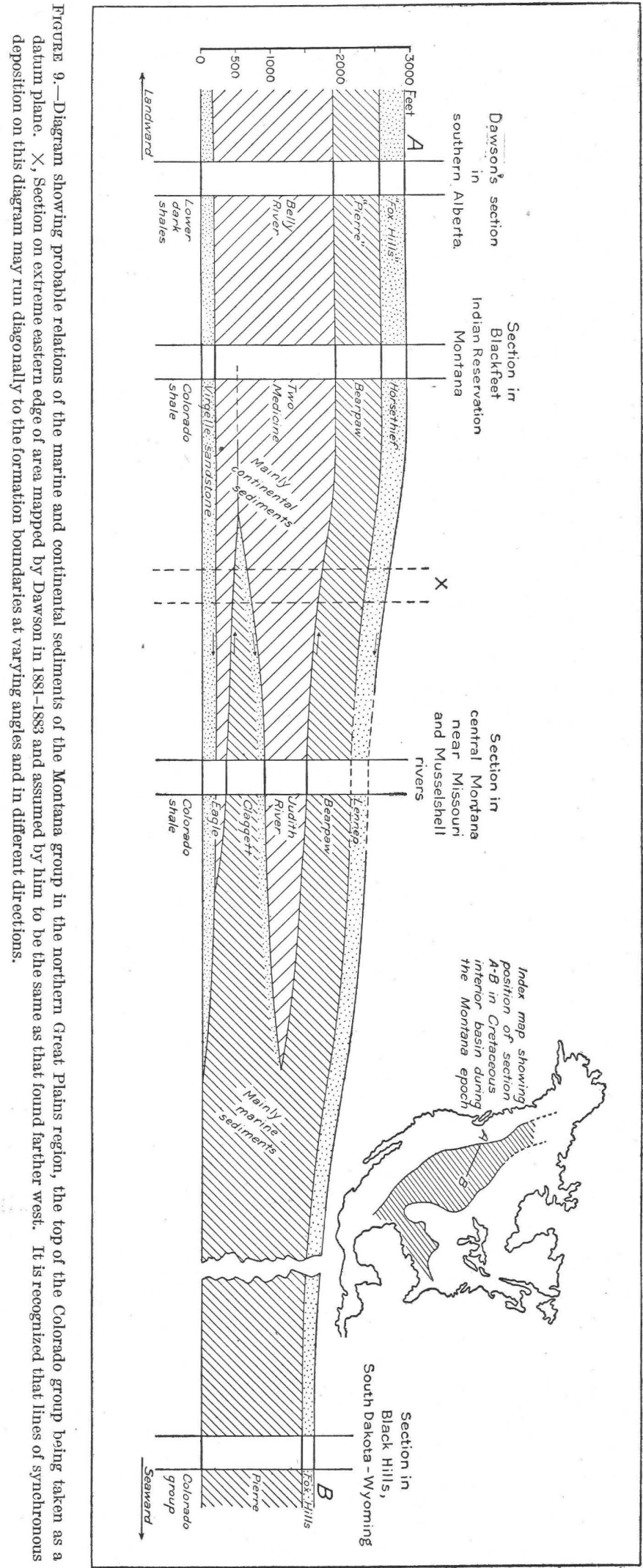


the upper part of the Claggett-was laid down. This recession was immediately followed by a period of continental deposition, in which was formed the wedge of the Judith River formation; then a second advance - the Bearpaw-much more extensive than the Claggett, which, like the former advance, did not result in the deposition of any great amount of sand; and, lastly, a third and very extensive recession, probably the final one for the western part of the region considered, during which again a persistent and easily identifiable sandstone was laid down, this deposition being followed immediately by the piling up of continental sediments. The deposition of a sand upon each retreat of the sea in contrast to the practical absence of such a sand on each advance is a notable phenomenon in this sedimentary record, and seems to indicate that each retreat of the sea was accompanied by land uplift with an increase in stream gradients and consequent coarsening of sediments and each advance by the opposite conditions. The close similarity between these three sandy formations is further brought out by the fact that they contain littoral marine faunas, those of the Fox Hills and Horsethief sandstones and the sandstone at the top of the Claggett being practically identical and that of the Virgelle being a direct forerunner of later faunas.

Above the Horsethief sandstone in the section on Two Medicine River there are lightcolored soft clayey and sandy strata, already referred to as of continental origin, that are identical in appearance with the Belly River and Judith River strata. Although these rocks are younger than Montana in age, they deserve mention here because they seem to complete for a third time a cycle of sedimentation proceeding from purely marine to fresh-water or continental conditions. The first of these cycles is from the marine Colorado shale, through Virgelle sandstone, to the strata of continental origin in the lower part of the Two Medicine formation; the second is from the marine shale of the Claggett, through the sandstone in its upper part to strata, also of continental origin, comprising the Judith River formation; and the third is from the marine Bearpaw, through the Horsethief sandstone, to the continental deposits above that sandstone. The relations in each cycle between the continental deposits and the underlying sandstone seem to be identical. The strata are apparently perfectly conformable and the impression is very strong that the same conditions ruled in each transition from marine to land conditions, or, in other words, the strata above the Horsethief sandstone are physically as closely related to the Bearpaw shale as the Judith River formation is to the Claggett or the Two Medicine formation to the Colorado shale. Now, these strata of continental origin above the Horsethief sandstone constitute the St. Mary River beds of Dawson, which occupy the same position in the geologic column as the Edmonton formation of central Alberta and approximately that of the Lance formation of Wyoming. The age of this formation is therefore involved in the Lance-Laramie problem of North American geology, and in the opinion of the writer the fact that in this part of the interior basin this formation, which seems to be equivalent to the Lance, appears to be as intimately related stratigraphically to Cretaceous marine shale below it as are similar continental deposits well down in the Cretaceous section to a corresponding marine shale should receive considerable weight in the consideration of that problem.

Lastly, the sedimentary record that has been described seems noteworthy because it shows three successive marked recessions of a sea which are not known to have produced unconformity or other hiatus in the stratigraphy-conditions commonly attendant on such recessions-but, on the contrary, seem to have been followed immediately by sedimentation at an increased rate, the strata deposited bearing conformable relations to the underlying rocks. The proper concept seems to be that each recession of the Upper Cretaceous sea in the northern interior region of North America was accompanied in extensive areas of lowlands on its margins not by uplift and erosion but by uplift and an increased rate of sedimentation. 